\title{
MASALAH SARA YANG TERUS BERMUNCULAN DAN HUKUM YANG BISA DIPERJUAL BELIKAN YANG TERJADI DI INDONESIA
}

\author{
Sindu Dwi Mardhani \\ Prodi Teknik Industri Universitas Katolik Widya Mandala Surabaya \\ Kampus Madiun \\ Sindudm@gmail.com
}

\begin{abstract}
ABSTRAK
Kondisi yang diangkat antara lain masalah sara yang terus bermunculan dan hukum yang bisa diperjual belikan yang terjadi di Indonesia. filsof tentang anggapan manusia berasal dari tanah dan akan kembali ketanah serta intelek, kehendak, dan dinamik manusia Lebih jauh dari itu filsafat memberikan pandangan yang luas sehingga manusia dapat membendung egoisme dan egosentrisme, membebaskan manusia dari belenggu cara berfikir yang sempit, memberikan landasan historis-filosofis bagi setiap kajian disiplin ilmu yang ditekuni, memberikan nilai dan orientasi yang jelas bagi setiap disiplin ilmu. Dilihat dari segi filsof seharusnya tidak perlu ada kasus pembakaran tempat ibadah karena pada dasarnya manusia sudah dibekali dengan pandangan cara hidup, dan pandangan dunia memberikan ajaran tentang moral dan etika yang berguna dalam kehidupan memehami diri sendiri dan dunia, menembangkan kemampuan dalam menalar, dan memberikan bekal untuk memperhatikan pandangan diri sendiri dan orang lain dengan keritis. Kasus hukum yang terjadi di Indonesia yaitu tumpul ke atas dan tajam kebawah, contoh kasus mal praktek RSUD Sangatta Kutai Timur yang menyebabkan korban bocah dibawah umur buta seumur hidup pada tahun 2013 tanpa ada tunjangan pada anak tersebut, sepeserpun cuam doter yang melakukan mal praktek tersebut di tutup tempat prakteknya selama 3 bulan setelah itu tidak ada kelanjutan tentang masadepan anak tersebut.
\end{abstract}


Seharusnya hal seperti itu harus di tindak lanjuti untuk kedepannya padahal anak terebut sudah mengalami buta total dan masa depanya sudah tidak ada lagi. Untuk pihak dokter juga tidak memiliki pikiran untuk menujang biaya hidup seumur hidup anak tersebut, padahal pada filsof manusia di satu pihak mempunyai kebebasan, tatapi di lain pihak juga tergantung. Ketika memutuskan, manusia bebas, tatapi setelah itu ia harus tunduk pada apa yang sudah diputuskan. Jadi segala yang sudah diputuskan itu harus dipertanggung jawabkan tentang apa yang sudah dia lakukan.

Kata Kunci : Tata cara hidup, ketentuan, tanggung jawab

\section{A. PERMASALAHAN ATAU FENOMENA YANG DIHADAPI}

Kondisi yang diangkat antara lain masalah sara yang terus bermunculan dan hukum yang bisa diperjual belikan yang terjadi di Indonesia jika semua itu ditinjau dari dimesi dasar manusia dan pendapat para filsof tentang manusia yang berasal dari tanah dan akan kembali ke tanah.

\section{B. TEORI YANGDIGUNAKAN}

Teori yang digunakan untuk manganalisis masalah serta fenomena itu yaitu pandangan filsof tentang anggapan manusia berasal dari tanah dan akan kembali ketanah serta intelek, kehendak, dan dinamik manusia.

\section{PEMBAHASAN MASALAH DAN FENOMENA}

Filsafat membantu manusia untuk mencari kebenaran dari fenomena yang ada, memberikan tentang cara hidup, dan pandangan dunia, memberikan ajaran tentang moral dan etika yang berguna dalam kehidupan memahami diri sendiri dan dunia, mengembangkan kemampua dalam bernalar, dan memberikan bekal untuk memeprhatikan pandangan diri sendiri dan orang lain dengan keritis. Lebih jauh dari itu filsafat memberikan pandangan yang luas sehingga manusia dapat membendung egoisme dan ego-sentrisme, membebaskan manusia dari belenggu cara berfikir yang sempit, memberikan 
landasan historis-filosofis bagi setiap kajian disiplin ilmu yang ditekuni, memberikan nilai dan orientasi yang jelas bagi setiap disiplin ilmu.

Berfilsafat memperlukan kedalaman, pencarian yang tak kunjung berhenti dalam terang rasionalitas, yang dilakukan dengan kaidah-kaidah yang bisa di pertanggung jawabkan. Jika dilakukan suatu kontemplasi lebih lanjut, maka manfaat filsafat secara radikal adalah menjadikan seorang bijaksana dalam hal menyikapi masalah hidup dan kehidupan karena telah berteman dengan kebijaksanaan, serta mengetahui dengan benar apa tujuan merka berbuat sehingga filsafat di berbagai tempat berperan sebagai pandangan hidup, pegangan hidup behkan sebagai pedoman hidup.

Kata "Manusia" secara etimologis berasal dari bahasa sansekerta: manusya. Bahasa Inggris humman, dari kata latin homo, yang berasal dari kata humus (tanah). Dari situ maka kita tidak boleh terlalu mengagungkan dan terlalu merendahkan kemanusiaan. Manusia ternyata masih belum bisa mengenali dirinya secara penuh. Manusia kemudian mencari kodratnya. Dahulu kodrat ini mengandung pengertian bahwa ia harus diijinkan, tatapi sekarang kodrat dialami sebagai suatu gudang persediaan yang harus dikuras karena IPTEK membuka eksploritasi terhadapnya (misalnya cloning). Lalu pertanyaanya adalah : apakah hakekat manusia ? pertanyaan ini melampaui semua penelitian empris, dan inilah pergumulan filsafat manusia. Dari ini filsafat manusia menjadi ilmu tersendiri, karena ilmu empris lain tidak mampu menjawabnya.

Indonesia adalah negara yang masih berkembang. Tujuh tahun indonesia merdeka masih belum membuat indonesia segera menjadi negara maju. Justru beberapa tahun, indonesia mengalami masa-masa sulit yang membuatnya justru mundur secara perlahan. Banyak hal besar yang menjadi polemik atau masalah besar tak kunjung menemui titik terang.

Negara yang memiliki banyak sekali suku bangsa. Selain itu negara ini juga memiliki 6 agama resmi dijalankan secara berdampingan. Itulah Binneka Tunggal Ika yang menjadi semboyan Indonesia. Sayangnya dalam beberapa hal, keberagaman ini justru menjadi masalah yang sangat besar. Bahkan bisa 
memicu suatu bentrokan hingga perang. Masalah terbaru adalah kasus pembakaran masjid di Tolikara dan pembakaran Gereja di Singkil. Masalah seperti itu seharusnya bisa diselesaikan dengan baik. Dengan begitu di kemudian hari tidak akan muncul masalah yang sama.

Dilihat dari segi filsof seharusnya tidak perlu ada kasus pembakaran tempat ibadah karena pada dasarnya manusia sudah dibekali dengan pandangan cara hidup, dan pandangan dunia memberikan ajaran tentang moral dan etika yang berguna dalam kehidupan memehami diri sendiri dan dunia, menembangkan kemampuan dalam menalar, dan memberikan bekal untuk memperhatikan pandangan diri sendiri dan orang lain dengan keritis. Menjadikan seorang menjadi bijaksana dalam hal menyikapi masalah hidup dan kehidupan, karena telah berteman dengan kebijaksanaan, mengetahui dengan benar apa tujuan mereka berbuat sehingga filsafat di berbagai tempat berperan sebagai pandangan hidup, pegangan hidup bahkan sebagi pedoman hidup seorang manusia sehingga tidak perlu adanya konfilik antar umat beragama.

Manusia disuatu pihak mempunyai kebebasan, tetapi dilain pihak juga tergantung. Ketika memutuskan, manusia bebas, tetapi setalah itu ia harus tunduk pada apa yang sudah diputuskan. Aliran determinisme mengatakan bahwa manusia itu tidak bebas dan ditentukan oleh unsur-unsur lain. (Hegel : dialetika Roh, Spinoza : substansi penentu segala sesuatu, dan Carl Gustav Jang : manusia bergantung pada hukum yang ada) sedangkan aliran indeterminisme mengatakan manusia itu bebas mutlak (Fichte : manusia mementukan dirinya sendiri, Atomitis : semua adalah peristiwa atom yang terjadi secara kebetulan). Konflik dalam memahami tentang kebebasan terjadi antara paham determinisme dan indeterminisme.

Masalah hukum yang bisa dijual dan dibeli. Hukum adalah suatu yang sangat penting disemua negara termasuk di Indonesia. Namun permasalahan hukum di Indonesia begitu pelik hingga masyarakat tidak percaya lagi dengan pengadilan. Banyak sekali kasus-kasus yang janggal hingga memenangkan pihak yang seharusnya salah. Hukum di Indonesia sudah seperti perdagangan 
yang bisa dibeli dan dijual. Kasus hukum yang terjadi di Indonesia yaitu tumpul ke atas dan tajam kebawah, contoh kasus mal praktek RSUD Sangatta Kutai Timur yang menyebabkan korban bocah dibawah umur buta seumur hidup pada tahun 2013 tanpa ada tunjangan pada anak tersebut, sepeserpun cuam doter yang melakukan mal praktek tersebut di tutup tempat prakteknya selama 3 bulan setelah itu tidak ada kelanjutan tentang masadepan anak tersebut.

Seharusnya hal seperti itu harus di tindak lanjuti untuk kedepannya padahal anak terebut sudah mengalami buta total dan masa depanya sudah tidak ada lagi. Untuk pihak dokter juga tidak memiliki pikiran untuk menujang biaya hidup seumur hidup anak tersebut, padahal pada filsof manusia di satu pihak mempunyai kebebasan, tatapi di lain pihak juga tergantung. Ketika memutuskan, manusia bebas, tatapi setelah itu ia harus tunduk pada apa yang sudah diputuskan. Jadi segala yang sudah diputuskan itu harus dipertanggung jawabkan tentang apa yang sudah dia lakukan.

Jadi apa dari yang tejadi dari kasus di atas yaitu manusia sekarang sudah melupakan hakekatnya sebagai manusia padahal manusia dapat berfikir memahami diri sendir dan dunia, mengembangkan kemampuan dalam menalar, dan memberikan bekal untuk memperhatikan pandangan diri sendiri dan orang lain dengan keritis. Berfilsafat memperlukan kedalaman, pencarian tak kunjung henti dalam terang rasionalitas, yang dilakkan dengan kaidah-kaidah yang bisa dipertanggung jawabkan. Jika dilakukan suatu kontemplasi lebih lanjut, maka manfaat filsafat secara radikal adalah menjadikan seseorang bijaksana dalam hal menyikapi masalah hidup.

Plato mengakui adanya faktor positif pada kelompok sofis itu, yaitu mereka membersihkan pemikiran dari pandangan-pandangan yang bisa menjadi hambatan bagi pengetahuan jiwa. Dengan hal lain perkataan, mereka menjalankan juga suatu fungsi kritis yang sehat di bidang pemikiran. Tatap muka dengan plato (427-345 SM) berati perjumpaan dengan suatu pandangan filsofis tentang dunia dan manusia yang luar biasa. Visinya sangat spiritualitis. Tampak bagai mana perjalanan filsafat dulu berfokus pada alasan semesta, lambat laun menganggap pula tentang manusia. 
Manusia tidak pernah berhenti bergerak, membawa diri. Sel bertumbuh, mengadakan diferensiasi, mengadakan organ-organ, ahirnya lahir sebagai bayi. Terus bertumbuh, berkembang terus mempertahankan diri, organorgan badan bekerja, darah berputar dan sebagainya. Hidup berati aktif terus. 